\title{
Effects of Body Weight and Nutrition on Mammary Protein Expression Profiles in Holstein Heifers
}

\author{
K. M. Daniels, ${ }^{\star}$ K. E. Webb, Jr.,† M. L. McGilliard, ${ }^{\star}$ M. J. Meyer,‡ M. E. Van Amburgh,‡ and R. M. Akers ${ }^{\star 1}$ \\ *Department of Dairy Science, and \\ †Department of Animal and Poultry Sciences, Virginia Polytechnic Institute and State University, Blacksburg 24061 \\ $\ddagger$ Department of Animal Science, Cornell University, Ithaca, NY 14853
}

\section{ABSTRACT}

A proteomics approach was used to characterize biochemical and cellular mechanisms governing effects of peripubertal feeding on heifer mammary development. Mammary parenchymal tissue from 24 Holstein heifers randomly assigned to treatments arranged in a $2 \times 2$ factorial design was used to generate 2-dimensional protein maps of mammary tissue extracts. Heifers were reared on 1 of 2 dietary treatments, restricted (650 g/ $\mathrm{d}$ of daily gain) or elevated ( $950 \mathrm{~g} / \mathrm{d}$ of daily gain) and killed at 1 of 2 body weights (BW, 200 or $350 \mathrm{~kg}$ ). Cytosolic mammary gland extracts were prepared from frozen mammary parenchyma. Proteome maps of extracts were constructed using PDQuest software. Densities of 820 protein spots were analyzed using the MIXED procedure of SAS. Protein spots were characterized by changes in profiles of expression in response to increased BW, dietary treatment, or both. Dietary treatment influenced the expression of 131 protein spots, whereas heifer BW influenced the expression of 108 spots. The 22 most highly influenced (statistically) spots were excised and submitted for mass spectrometric analyses. Returned protein names and accession numbers were used in National Center for Biotechnology Information database searches to obtain information on the identified proteins. For example, one of the proteins that differed by dietary treatment, transferrin, a binding protein of insulin-like growth factor binding protein-3, was identified via these methods. Possible roles of this and other proteins in mammary development are described. We concluded that a proteomic approach is an effective tool for identifying the proteins involved in bovine mammary development.

Key words: heifer, mammary, nutrition, proteome

\section{INTRODUCTION}

Mammary development is critical to the future production of dairy cows. In many situations, reduced

Received June 2, 2005.

Accepted August 3, 2006.

${ }^{1}$ Corresponding author: rma@vt.edu mammary gland development in prepubertal heifers reared on high planes of nutrition coincides with the failure of adequate allometric growth of the mammary gland in the peripubertal period. Allometric mammary growth occurs when the udder grows at a faster rate than the rest of the body; in heifers, allometric growth of the mammary fat pad and of mammary ducts begins between 2 and 3 mo of age (or roughly $100 \mathrm{~kg}$ of BW; Sinha and Tucker, 1969). Once a heifer reaches puberty between 9 and $11 \mathrm{mo}$ of age ( 250 to $280 \mathrm{~kg}$ of BW), the mammary gland returns to an isometric rate of growth, and thereafter, there seems to be no effect of feeding level on mammary development (Sejrsen et al., 1982). Despite considerable understanding of the effects of peripubertal feeding level on general udder growth and performance, the biochemical and cellular mechanisms governing heifer mammary gland development are poorly understood.

An untested approach to studying mammary development in dairy heifers is the use of proteomics, which is the study of the complete set of translated proteins in a given biological sample. The proteome, rather unlike the genome, changes in response to experimental conditions, such as an elevated (E) or restricted (R) feeding level, the stage of development, or both. To date, no reports have been published on the construction of a 2-dimensional PAGE (2D-PAGE) database of bovine mammary gland proteins from growing heifers. However, Aksu et al. (2002) described the creation of a mouse mammary gland 2D-PAGE protein database containing more than 4,250 total protein spots and 66 specifically identified proteins. Regardless, proteomic experiments specific to dairy heifers are essential because relational maps for mouse proteins are ineffective in the identification of most bovine counterparts (Talamo et al., 2003).

The objectives of this experiment were 1) to create 2dimensional protein maps of mammary tissue extracts from heifers that were reared on 1 of 2 planes of nutrition and killed at 1 of 2 different BW, and 2) to identify selected individual proteins whose expression profiles changed most significantly in response to increased BW, plane of nutrition, or both. Although age is a good 
general predictor of the onset of puberty, Sejrsen (1994) observed that in dairy heifers, puberty is more closely associated with BW than age; this is why we chose to evaluate peripubertal heifers based on BW rather than on chronological age.

\section{MATERIALS AND METHODS}

\section{Animals and Treatments}

The mammary tissue samples used in this study were a subset of samples from animals that were purchased within $1 \mathrm{wk}$ of age from dairy farms surrounding Ithaca, New York, and treated at Cornell University, as described in detail in a companion paper (Meyer et al., 2006a). Briefly, animals $(n=24)$ were randomly assigned to either an $\mathrm{E}$ or $\mathrm{R}$ level of nutrient intake supporting 950 or $650 \mathrm{~g}$ of daily BW gain. Within treatments, heifers were assigned to 1 of 2 harvest points (200 or $350 \mathrm{~kg}$ of BW, respectively). The $200-\mathrm{kg}$ harvest weight encompasses a physiological period when allometric mammary gland growth is predominant, and the $350-\mathrm{kg}$ harvest weight, a period of postpubertal isometric growth of the mammary gland. These harvest weights were based on the temporal pattern of mammary development observed by Sinha and Tucker (1969). Six heifers per dietary treatment were killed at each BW.

Heifers on the $\mathrm{R}$ dietary treatment were fed a preweaning diet that consisted of $22 \% \mathrm{CP}$ and $21 \%$ fat milk replacer that was fed at $0.20 \mathrm{Mcal}$ of gross energy $/ \mathrm{kg}$ of $\mathrm{BW}^{0.75}$. Heifers on the E dietary treatment were fed a preweaning diet that consisted of a $29 \% \mathrm{CP}$ and $19 \%$ fat milk replacer that was fed at 0.32 Mcal of gross energy $/ \mathrm{kg}$ of $\mathrm{BW}^{0.75}$. Weaning was initiated after approximately 6 wk on the treatment. A textured calf starter was offered to animals from 3 wk on the study through $10 \mathrm{wk}$ on the study. From $10 \mathrm{wk}$ to the end of the treatment period, all heifers were fed a TMR. Composition of the milk replacer, starter, and TMR was described in a companion paper (Meyer et al., 2006a) Heifers were weighed weekly, and the amount of feed offered was adjusted throughout the trial such that heifers on the $R$ treatment could achieve $650 \mathrm{~g}$ of daily gain, and heifers on the $\mathrm{E}$ treatment could achieve 950 $\mathrm{g}$ of daily gain. From the initiation of treatment to 150 $\mathrm{kg}$ of BW, heifers were housed in individual pens in the Teaching and Research Dairy Center Greenhouse at Cornell University. Upon reaching $150 \mathrm{~kg}$ of BW, heifers were grouped in one pen and individually fed via a Calan gate system (American Calan; Northwood, NH). Once heifers assigned to slaughter weights greater than or equal to $250 \mathrm{~kg}$ reached $225 \mathrm{~kg}$ of $\mathrm{BW}$, blood was collected twice weekly via jugular venipuncture, and plasma progesterone concentrations were determined.
Progesterone concentrations above $1 \mathrm{ng} / \mathrm{mL}$ were interpreted as the heifer having a functional corpus luteum, and the heifer was therefore considered pubertal.

\section{Mammary Tissue Collection}

Heifers were weighed weekly to monitor the target rate of gain. The approximate ages at each harvest point (for the $\mathrm{R}$ and $\mathrm{E}$ dietary treatments, respectively) were $200 \mathrm{~kg}, 265$ and $183 \mathrm{~d}$; and $350 \mathrm{~kg}, 467$ and 338 $\mathrm{d}$. The decision to harvest at a common BW as opposed to a common age was based on observations that puberty is more closely associated with BW than age (Sejrsen, 1994). Animals were killed at the Department of Animal Science Abattoir at Cornell University using a captive bolt stunner followed by exsanguination. Pubertal heifers were killed during the luteal phase of their estrous cycle. At harvest, the udder of each heifer was bisected along the medial suspensory ligament. Parenchymal tissue samples from the midgland region relative to the teat were excised from one quarter of the left udder half of each animal and were stored at $-20^{\circ} \mathrm{C}$ until shipment. Frozen mammary tissue samples were shipped overnight on dry ice to Virginia Tech. Upon arrival, samples were placed in a $-80^{\circ} \mathrm{C}$ freezer until use. Additionally, representative samples of midgland parenchymal tissue from all animals were fixed and processed for histology. No diet or harvest weight differences in percentages of epithelium, lumen, or intra- and interlobular stroma were detected in the parenchymal samples evaluated (Daniels et al., 2005). Mammary parenchyma and fat pad mass and composition, as well as epithelial cell proliferation, parenchymal accretion rate, and allometric growth data pertaining to these heifers are described in detail in the companion papers (Meyer et al., 2006a,b).

\section{Preparation of Mammary Gland Extracts}

Mammary tissue extracts were prepared essentially according to Waksman et al. (1991). Briefly, $2 \mathrm{~g}$ of frozen mammary tissue was weighed and homogenized in a polytron homogenizer (Kinematica, Lucerne, Switzerland) for $15 \mathrm{~s}$ in a total volume of $10 \mathrm{~mL}$ of $0.9 \% \mathrm{NaCl}$. Homogenates were gently rocked for $90 \mathrm{~min}$ at $4^{\circ} \mathrm{C}$ on a Speci-Mix platform rocker (Thermolyne Corporation, Dubuque, IA) before being centrifuged at $10,000 \times g$ at $4^{\circ} \mathrm{C}$ for $20 \mathrm{~min}$ to remove cell debris. The supernatant was retained and centrifuged at $100,000 \times g$ for $1 \mathrm{~h}$. The resulting supernatant (cytosol) was then filtered through $0.2-\mu \mathrm{m}$ Acrodisc syringe filters (Pall Corporation, Ann Arbor, MI) and stored in a series of sterile microfuge tubes at $-80^{\circ} \mathrm{C}$ for subsequent analyses.

Samples were thawed at room temperature and then desalted using Microcon Y-3 centrifugal filter devices 
[Millipore Corporation; Bedford, MA; 3,000 nominal molecular weight (Mw) limit in daltons]. Specifically, $300 \mu \mathrm{L}$ of mammary gland extract was placed in the sample reservoir, and the devices were then centrifuged at room temperature at $14,000 \times g$ for $50 \mathrm{~min}$. Samples were processed in triplicate. The filter was then washed twice with $100 \mu \mathrm{L}$ of deionized water $(14,000 \times \mathrm{g}$, room temperature for $30 \mathrm{~min}$ ). The retentate was collected into a clean microfuge tube by flipping the reservoir over and centrifuging the device $(1,020 \times g ; 3 \mathrm{~min})$. Two hundred microliters of deionized water was then added to the retentates, and triplicate samples were pooled. Protein concentrations of the pooled aliquots were determined via the bicinchoninic acid assay (Pierce, Rockford IL); BSA was used as the standard. Protein concentrations of extracts ranged from 2.2 to $12.2 \mu \mathrm{g} / \mu \mathrm{L}$. Samples were stored at $-80^{\circ} \mathrm{C}$.

\section{D-PAGE}

Immobilized $\mathrm{pH}$ gradient (IPG) strips (ReadyStrip, 18 cm, pH 3-10 NL; Bio-Rad Laboratories, Hercules, CA) were actively rehydrated with $300 \mu \mathrm{L}$ of solubilized sample [315 $\mu \mathrm{g}$ of protein brought to volume with the following buffer: $12.2 \mathrm{~g}$ of urea, $3.8 \mathrm{~g}$ of thiourea, $2 \mathrm{~mL}$ of $50 \% 3$-[(3-cholamidopropyl)dimethylammonio]-1propanesulfonate (Fisher Scientific, Pittsburgh, PA), 50 $\mathrm{mL}$ of Bio-Lyte 3/10 (Bio-Rad Laboratories), brought to a final volume of $25 \mathrm{~mL}$ with Milli-Q water, $250 \mu \mathrm{L}$ of $200 \mathrm{~m} M$ tributylphosphine (Bio-Rad), and $0.192 \mathrm{~g}$ of dithiothreitol (Bio-Rad) added just prior to use] for 13 $\mathrm{h}$ at $50 \mathrm{~V}$, at a temperature of $20^{\circ} \mathrm{C}$ in a Protean IEF cell (Bio-Rad Laboratories). Focusing parameters for the subsequent electrophoresis were as follows: start voltage of $0 \mathrm{~V}$, end voltage of $10,000 \mathrm{~V}, 60,000$ total $\mathrm{Vh}$, rapid ramping, $20^{\circ} \mathrm{C}$, run time approximately 11 h. Immediately after being focused, IPG strips were equilibrated for $3 \times 30 \mathrm{~min}$ with $3 \mathrm{~mL}$ of the appropriate equilibration buffer (EB). Equilibration buffer 1 consisted of $72 \mathrm{~g}$ of urea, $40 \mathrm{~mL}$ of $20 \%$ SDS, $37 \mathrm{~mL}$ of 2 $M$ Tris (pH 8.8), and $40 \mathrm{~mL}$ of glycerol brought to a 200-mL volume with Milli-Q water (1 $\mathrm{g}$ of dithiothreitol was added to $50 \mathrm{~mL}$ of EB1 to constitute EB2; $1.2 \mathrm{~g}$ of iodoacetamide was added to $50 \mathrm{~mL}$ of EB1 to constitute EB3). After equilibration, each IPG strip was gently pushed in contact with the second-dimension gel surface with a spatula and was then set in place using a $0.5 \%$ agarose solution containing bromophenol blue. Second-dimension gels consisted of a hand-cast stacking gel (6\% acrylamide plus crosslinker) that was cast on top of $20 \times 20.5(\mathrm{w} \times \mathrm{l}) \mathrm{cm}, 1.0 \mathrm{~mm}$ hand-cast 8 to $16 \%$ (total percentage of acrylamide plus crosslinker) gradient gel. The second-dimension electrophoresis was completed in a Protean Plus Dodeca cell (catalog \#165-
4151; Bio-Rad Laboratories) containing $24 \mathrm{~L}$ of $1 \times$ Tris, glycine, SDS buffer (made from the following $10 \times$ stock buffer: $60.57 \mathrm{~g}$ of Tris base, $288.26 \mathrm{~g}$ of glycine, and 20 $\mathrm{g}$ of SDS, brought to a 2-L volume with Milli-Q water) that was connected to a circulating water bath. Electrophoresis was performed at 20 to $25^{\circ} \mathrm{C}$ at a constant voltage of $200 \mathrm{~V}$. The power supply was turned off when the bromophenol blue dye front was within $2 \mathrm{~cm}$ of the edge of the gel cassettes (after approximately $9 \mathrm{~h}$ ). Immediately after electrophoresis, the resolved proteins in each 2D-PAGE gel were fixed for $30 \mathrm{~min}$ in approximately $330 \mathrm{~mL}$ of a Milli-Q water-glacial acetic acid-methanol (8:1:1) solution. After fixing, individual gels were stained for $14 \mathrm{~h}$ with approximately $330 \mathrm{~mL}$ of $100 \%$ Sypro Ruby protein gel stain (Bio-Rad Laboratories). After staining, gels were subjected to four 1-h washes with fresh fixing solution. Gels were kept in the fourth wash until imaging the next day. Protein gel stain was decanted after each use into its original container, and the same $4 \mathrm{~L}$ of stain was used for all 2DPAGE runs. A Molecular Imager FX Pro Plus MultiImager System (Bio-Rad Laboratories) was used to visualize each gel. Gels were individually packaged in thick plastic wrap with fixing solution and stored at room temperature away from ambient light after digitized images of the gels were obtained. Three gels were run for each animal.

\section{Image Analysis}

Raw images of the gels were incorporated into the PDQuest program (Bio-Rad), where they were cropped, filtered, and compiled into a Matchset. Individually resolved protein spots were enumerated, assigned an arbitrary spot identification number based on location in the gel, and quantified based on signal intensity. The isoelectric point (pI) and $\mathrm{Mw}$ of each protein spot were calculated with respect to standards included in the electrophoresis runs (2D SDS-PAGE Standards, \#1610320; Bio-Rad Laboratories; Precision Plus Protein Standard Plugs, unstained, \#161-0378; Bio-Rad Laboratories). Matchset data ( $\mathrm{pI}$ and $\mathrm{Mw}$ information, and normalized spot quantities) were exported as a file that was accessible through Microsoft Excel.

\section{Statistical Analysis}

In the MIXED procedure of SAS (Version 8.0; SAS Institute, Inc., Cary, NC), main effects of diet and harvest weight, as well as the interaction between the 2 were tested. Heifer within the combination of diet and target weight was a random term. The dependent variable used in the final analysis was normalized protein spot quantity at each of 820 total protein spots. Diet 
was either $\mathrm{R}$ or $\mathrm{E}$, and target harvest weights were 200 or $350 \mathrm{~kg}$. The following model statement was used:

$$
\mathrm{Y}_{\mathrm{ijkl}}=\mu+\mathrm{D}_{\mathrm{i}}+\mathrm{W}_{\mathrm{j}}+(\mathrm{DW})_{\mathrm{ij}}+\mathrm{H}_{(\mathrm{ij}) \mathrm{k}}+\mathrm{E}_{(\mathrm{ijk}) \mathrm{l}}
$$

where $\mathrm{Y}_{\mathrm{ijkl}}$ is the dependent variable (normalized protein spot quantity); $\mu$ is the overall mean; $D_{i}$ is the fixed effect of diet (R vs. E, $\mathrm{i}=1,2$ ); $\mathrm{W}_{\mathrm{j}}$ is the fixed effect of target weight ( 200 vs. $350 \mathrm{~kg}, \mathrm{j}=1,2$ ); $\mathrm{DW}_{\mathrm{ij}}$ is the effect of the interaction of diet and target weight; $\mathrm{H}_{(\mathrm{ij}) \mathrm{k}}$ is the random effect of heifer within the combination of diet and target weight ( $\mathrm{k}=1,6$ heifers within a subclass); and $\mathrm{E}_{(\mathrm{ijk}) l}$ is the residual error (sampling within heifer, $l=1,3)$.

Because of the exploratory nature of this research, differences were considered significant at $P<0.20$; results are presented as least squares means \pm standard errors of the mean. A list of all statistically significant protein spots was exported into a Microsoft Excel spreadsheet. Separate spreadsheets were made for spots that differed by diet only, weight only, diet $\times$ weight only, and more than one of the previous effects.

\section{Protein Spot Excision and Protein Identification by Mass Spectrometry}

The spreadsheets with data that differed by diet and weight only were sorted by ascending $P$-values. Spot numbers with the smallest $P$-values were deemed the most interesting. A total of 22 spots ( $P$-values 0.002 to $0.15)$ were chosen for excision and subsequent mass spectrometric analyses; these 22 spots were processed in 1 of 2 batches. The first batch contained 10 excised protein spots and the second batch contained 12 protein spots. Protein spots of interest were excised from selected gels by a software-driven robotic cutter equipped with a 1.5-mm (i.d.) needle tip (Proteomeworks Spot Cutter; Bio-Rad Laboratories) and delivered into separate wells of a 96 -well plate filled with $100 \mu \mathrm{L}$ of $0.1 \%$ acetic acid.

On finishing, the 96-well plate containing the first batch of excised protein spots was removed from the cutting apparatus and the 96-well plate for the second batch of protein spots was placed on the apparatus. The plate from the first batch was scanned in the Molecular Imager FX Pro Plus MultiImager System to verify the deposition of protein plugs into the specified wells of the plate. The first plate was then heat-sealed and set aside. The spot-cutting protocol was then immediately repeated for the second batch of protein spots, which were cut from the same gel as the first batch. After all spot cutting was complete, the gel that was subjected to spot excision was rescanned, and its digital image was subsequently compared with the original scanned image of the gel to verify that the cutting program retrieved the correct protein spots. The sealed 96-well plates were then placed in a box and stored in a $-80^{\circ} \mathrm{C}$ freezer until mass spectrometric analyses.

Sealed 96-well plates were hand-delivered to the Core Laboratory Facility at the Virginia Bioinformatics Institute (VBI) on the campus of Virginia Tech on 2 separate occasions. On the first trip, the plate containing 10 protein spots was submitted; the plate containing the 12 other protein spots was processed approximately 1 wk later. At the VBI, each protein plug was subjected to trypsin digestion and mass spectrometric analysis to determine primary AA sequences, as well as recognized protein names. Once protein names and National Center for Biotechnology Information (NCBI) protein accession numbers were received from the VBI, literature searches were conducted. Known functions and characteristics of proteins were documented, along with possible roles in heifer mammary development.

\section{RESULTS AND DISCUSSION}

Actual harvest weights of the animals and actual daily gains of the animals are discussed in detail by Meyer et al. (2006a). Briefly, animals neared their targeted lifetime average daily gains (660 and $930 \mathrm{~g} / \mathrm{d}$ for $\mathrm{R}$ and $\mathrm{E}$, respectively) and were harvested near their target BW (least squares means of $205 \pm 2,205 \pm 2$, $360 \pm 3$, and $361 \pm 2 \mathrm{~kg}$, respectively, for $200-\mathrm{kg} \mathrm{E}, 200$ $\mathrm{kg} \mathrm{R}, 350-\mathrm{kg} \mathrm{E}$, and 350-kg R heifers). The decision to fix the BW as a discrimination point in this experiment resulted in heifers weighing the same at the time of animal sacrifice but being different in chronological age. The approximate ages at each harvest point (for $R$ and E dietary treatments, respectively) were $200 \mathrm{~kg}, 265$ and $183 \mathrm{~d}$; and $350 \mathrm{~kg}, 467$ and $338 \mathrm{~d}$. Thus, the reader should keep this in mind while reading about the proteins described below whose expression was affected by BW. Additionally, heifers killed at $200 \mathrm{~kg}$ were consuming a slightly different ration than heifers killed at 350 $\mathrm{kg}$ (Meyer et al., 2006a); the effects of BW discussed below may also have been influenced by differences in diet composition.

A total of 7 2D-PAGE runs were conducted for this experiment; 71 total gels were analyzed in the Matchset. Sixty-six of those represented gels from heifers, whereas 5 represented standard gels. At least 2 replicate gels were required of each heifer for inclusion in the Matchset, and gels from all 24 heifers were represented. A representative image of a $2 \mathrm{D}$ gel from this experiment is demonstrated in Figure 1. A total of 820 individual protein spots were statistically analyzed. Of these, 131 protein spots differed by diet only, 108 differed by heifer BW only, 101 had a significant diet $x$ 
$\mathrm{pH} 3$

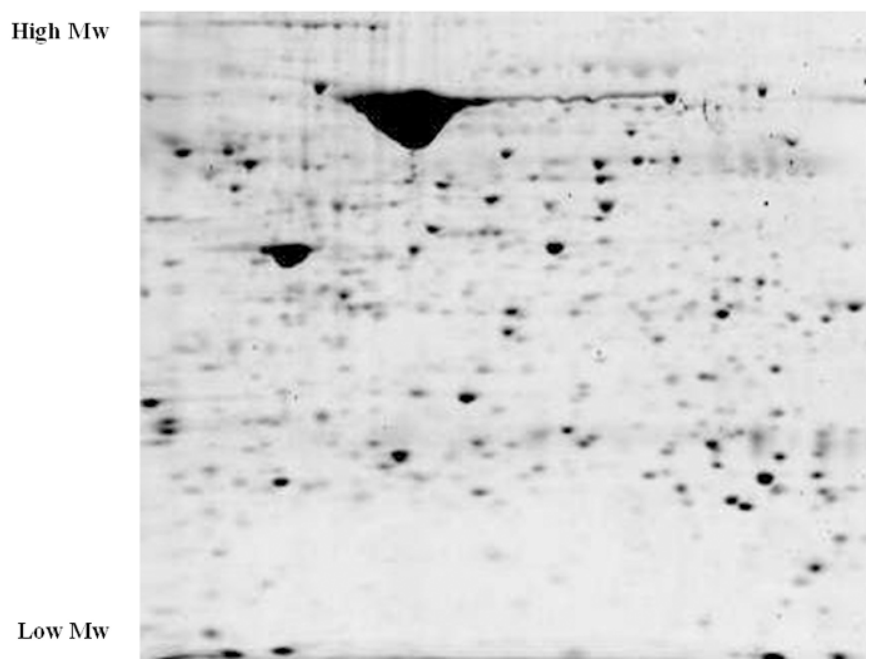

Figure 1. Representative image of heifer mammary parenchyma cytosol separated on a 2-dimensional gel and stained with Sypro Ruby protein gel stain (Bio-Rad Laboratories, Hercules, CA).

heifer BW interaction, and 135 differed by more than one of these variables.

A total of 22 protein spots were excised from $2 \mathrm{D}$ gels and submitted for mass spectrometric analysis. Of the 22 protein spots submitted for mass spectrometry, 15 of them were differentially expressed between heifers reared on different dietary treatments, and 7 were differentially expressed according to heifer BW (Table 1). Approximate $\mathrm{Mw}$ and $\mathrm{pI}$ for these particular spots are also listed in Table 1. Eighteen of the 22 proteins submitted for mass spectrometry were identified. Protein spots 3303 and 5602 were lost from the first microtiter plate during trypsin digestion. In the second batch, identities for protein spots 2606 and 7502 were inconclusive because of the strong presence of keratin contamination. Protein spot numbers and their corresponding protein names and NCBI protein accession numbers are listed in Table 2 for the first batch and in Table 3 for the second batch of protein plugs submitted to the VBI. The Gaussian Master Image annotated with identified proteins is displayed in Figure 2.

To our knowledge, a systematic proteomic analysis of peripubertal bovine mammary parenchyma cytosol has never been attempted or described before. Through our 2D-PAGE experiments, we found that the protein composition of bovine mammary cytosol fluctuated according to the physiological and nutritional state of heifers. Furthermore, through mass spectrometric analyses, we identified several differentially expressed proteins. A discussion of protein spots and identified proteins follows.

\section{Protein Spot 6707-Fascin}

Protein spot 6707 was identified as the protein fascin (Figure 2, Tables 1 and 2). Fascin is a cytoplasmic actinbundling/crosslinking protein that organizes filamentous actin into bundles. The bundling of actin into polymers, coupled with the action of actin-crosslinking proteins is generally essential for cell migration. Cell migration, especially lateral migration of epithelial cells, is important for mammary development to progress. This is because during normal mammary development, at least in humans, epithelial cells migrate to the tips of growing ducts, and once adulthood is reached, this migration is repressed (Anbazhagan et al., 1998). Fascin expression is typically low in normal epithelial cells, but has been found to be upregulated in metastatic estrogen receptor-negative breast cancer (Grothey et al., 2000). Interestingly, IGF-I receptor (IGF-IR) signaling also contributes to the formation of mammary carcinomas (Resnik et al., 1998) and affects the actin cytoskeleton (Kadowaki et al., 1986). In 2002, Guvakova et al. showed that breast carcinoma cell colonies dispersed in a time-dependent manner upon IGF-IR activation by IGF-I, and that the dissociation involved the formation of fascin-containing lateral cell projections. These observations imply a role for fascin in heifer mammary development, especially in nutritionally directed mammary development, as E-heifers, irrespective of BW, expressed nearly 1.8-fold more fascin protein $(P<0.004)$ than R-heifers (Table 1$)$. Serum IGF-I is generally more concentrated in heifers reared on a high feeding level (Vestergaard et al., 1995). It is therefore postulated that increased IGF-I serum levels in E-heifers may have led to increased IGF-IR signaling and therefore increased fascin protein expression, and ultimately cell migration.

\section{Protein Spot 8301-Guanine Nucleotide-Binding Protein $\beta$ Subunit-like Protein 12.3}

Protein spot 8301 was identified as guanine nucleotide-binding protein $\beta$ subunit-like protein 12.3 (protein 12.3; Figure 2, Tables 1 and 2), which is apparently similar to the $\beta$ subunit of the trimeric G-protein complex. It is classified as a signal transduction modulator. Trimeric G-proteins ( $\alpha, \beta$, and $\gamma$ subunits) are normally found on the cytoplasmic side of cell membranes and are known to couple with 7-transmembrane domain receptors when the receptor binds its natural ligand. The general signal-transduction pathway for G-protein-coupled receptors is as follows: On binding of ligand, the receptor activates a nearby G-protein that in turn activates the enzyme adenylate cyclase. Adenylate cyclase generates the cytoplasmic second messenger cyclic AMP. The increase in cyclic AMP triggers a chain 
Table 1. Characteristics of and differences in a normalized quantity of selected bovine mammary parenchyma cytosolic proteins separated by 2-dimensional PAGE and subsequently subjected to mass spectrometric analysis

\begin{tabular}{|c|c|c|c|c|c|c|c|}
\hline \multirow[b]{2}{*}{ Protein } & \multirow[b]{2}{*}{ Batch $^{1}$} & \multirow{2}{*}{$\begin{array}{l}\text { Estimated } \\
\mathrm{Mw}^{2}\end{array}$} & \multirow{2}{*}{$\begin{array}{l}\text { Estimated } \\
\mathrm{pI}^{3}\end{array}$} & \multirow{2}{*}{$\begin{array}{l}\text { Main } \\
\text { effect }\end{array}$} & \multicolumn{2}{|c|}{$\begin{array}{l}\text { Dietary treatment, } \\
\text { normalized quantity } \pm \text { SEM }\end{array}$} & \multirow[b]{2}{*}{$P$-value } \\
\hline & & & & & $\mathrm{R}$ & $\mathrm{E}$ & \\
\hline 3303 & 1 & 36.4 & 5.23 & Trt & $166 \pm 29$ & $306 \pm 27$ & 0.002 \\
\hline 6707 & 1 & 72.6 & 6.32 & Trt & $1,089 \pm 174$ & $1,872 \pm 170$ & 0.004 \\
\hline 7704 & 1 & 72.9 & 6.93 & Trt & $661 \pm 140$ & $1,297 \pm 136$ & 0.004 \\
\hline 8301 & 1 & 33.4 & -6 & Trt & $439 \pm 119$ & $931 \pm 117$ & 0.008 \\
\hline 7801 & 2 & 103.0 & 6.69 & Trt & $187 \pm 49$ & $391 \pm 43$ & 0.007 \\
\hline 6902 & 1 & 138.8 & 5.98 & Trt & $1,057 \pm 301$ & $2,138 \pm 290$ & 0.018 \\
\hline 8503 & 1 & 46.1 & - & Trt & $154 \pm 24$ & $227 \pm 23$ & 0.042 \\
\hline 2607 & 2 & 60.6 & 5.09 & Trt & $1,169 \pm 244$ & $1,863 \pm 241$ & 0.06 \\
\hline 2402 & 2 & 37.6 & 4.88 & Trt & $358 \pm 74$ & $550 \pm 73$ & 0.08 \\
\hline 6701 & 2 & 72.8 & 5.81 & Trt & $611 \pm 118$ & $913 \pm 114$ & 0.08 \\
\hline 2606 & 2 & 63.3 & 5.05 & Trt & $468 \pm 100$ & $714 \pm 98$ & 0.09 \\
\hline 7102 & 2 & 22.9 & 6.97 & Trt & $758 \pm 84$ & $967 \pm 80$ & 0.09 \\
\hline 7502 & 2 & 50.4 & - & Trt & $229 \pm 44$ & $331 \pm 41$ & 0.11 \\
\hline 3505 & 2 & 45.5 & 5.28 & Trt & $333 \pm 25$ & $279 \pm 24$ & 0.14 \\
\hline \multirow[t]{3}{*}{7101} & 2 & 24.0 & 6.73 & Trt & $202 \pm 34$ & $273 \pm 33$ & 0.15 \\
\hline & & & & & \multicolumn{2}{|c|}{$\mathrm{BW}, \mathrm{kg}$} & \\
\hline & & & & & 200 & 350 & \\
\hline 1702 & 1 & 76.0 & - & $\mathrm{Wt}$ & $1,842 \pm 173$ & $1,086 \pm 174$ & 0.006 \\
\hline 5602 & 1 & 60.6 & 5.65 & Wt & $1,922 \pm 159$ & $1,265 \pm 160$ & 0.009 \\
\hline 5705 & 1 & 75.5 & 5.70 & $\mathrm{Wt}$ & $2,813 \pm 249$ & $1,836 \pm 251$ & 0.01 \\
\hline 2403 & 2 & 42.6 & 4.93 & Wt & $441 \pm 77$ & $211 \pm 77$ & 0.05 \\
\hline 8108 & 1 & 24.6 & - & $\mathrm{Wt}$ & $804 \pm 83$ & $565 \pm 83$ & 0.05 \\
\hline 5605 & 2 & 67.4 & 5.77 & Wt & $471 \pm 132$ & $850 \pm 133$ & 0.06 \\
\hline 4601 & 2 & 60.0 & 5.41 & $\mathrm{Wt}$ & $706 \pm 80$ & $496 \pm 81$ & 0.08 \\
\hline \multicolumn{8}{|c|}{${ }^{1}$ Batch 1 was processed before batch 2.} \\
\hline \multicolumn{8}{|c|}{${ }^{2}$ Estimated molecular weight of the listed protein $(\mathrm{kDa})$. } \\
\hline \multicolumn{8}{|c|}{${ }^{3}$ Estimated isoelectric point of the listed protein $(\mathrm{pH})$} \\
\hline \multicolumn{8}{|c|}{$\begin{array}{l}{ }^{4} \text { Dietary treatment }(\mathrm{Trt}) \text { was either restricted }(\mathrm{R}) \text { or elevated }(\mathrm{E}) \text {; values are normalized quantity of } \\
\text { protein } \pm \text { standard error. }\end{array}$} \\
\hline \multicolumn{8}{|c|}{${ }^{5}$ Significance was declared at $P<0.20$} \\
\hline
\end{tabular}

of reactions regulated by protein kinases, with the ultimate consequence of evoking some intracellular response to the initial signal (Berg et al., 2002). Depending on the type of G-protein, adenylate cyclase is either stimulated to act or inhibited from acting. Known effectors of G-protein-coupled receptors include many peptide hormones and catecholamines. Notably absent from this list of effectors, however, are IGF-I, growth hormone, and estrogen, which all evoke cellular responses via other means. Known subtypes of G-proteincoupled receptors include $\alpha_{1}, \alpha_{2}, \beta_{1}, \beta_{2}$, and $\beta_{3}$. In the mammary gland of lactating cows, all subtypes are represented in the teat wall and large mammary ducts, but hardly any are present in parenchyma (Hammon et al., 1994). In general, milk removal is inhibited by the stimulation of $\alpha$-adrenergric receptors (contraction of smooth muscle) and increased by the stimulation of $\beta$-adrenergic receptors (relaxation of smooth muscle; Hammon et al., 1994). In the current study, E-heifers expressed over twice as much protein $12.3(P<0.008)$ compared with R-heifers. Given that adrenergic receptors in general are not present in great abundance in mammary parenchyma of lactating cows, it was interesting to find that a protein similar in composition to the $\beta$ subunit of the G-protein complex was so differentially expressed in our animals reared on different diets. The $\beta_{3}$ subclass of adrenergic receptors is associated with energy expenditure and adipocyte lipolysis, but is also the least abundant of the $\beta$ receptors in bovine mammary tissue (Inderwies et al., 2003). Based on our findings, we speculate that this subclass of $\beta$-adrenergic receptors is up-regulated in mammary parenchyma in heifers reared on an $\mathrm{E}$, rather than $\mathrm{R}$, diet. We propose that increased $\beta_{3}$-adrenergic receptor signaling in parenchymal adipocytes may cause increased lipolysis and thermogenesis in heifers reared on an $\mathrm{E}$, rather than R, diet. Our observations that mammary parenchyma cytosol from heifers reared on an $\mathrm{E}$ vs. R diet 
Table 2. Components of protein spots determined by mass spectrometry (batch 1$)^{1}$

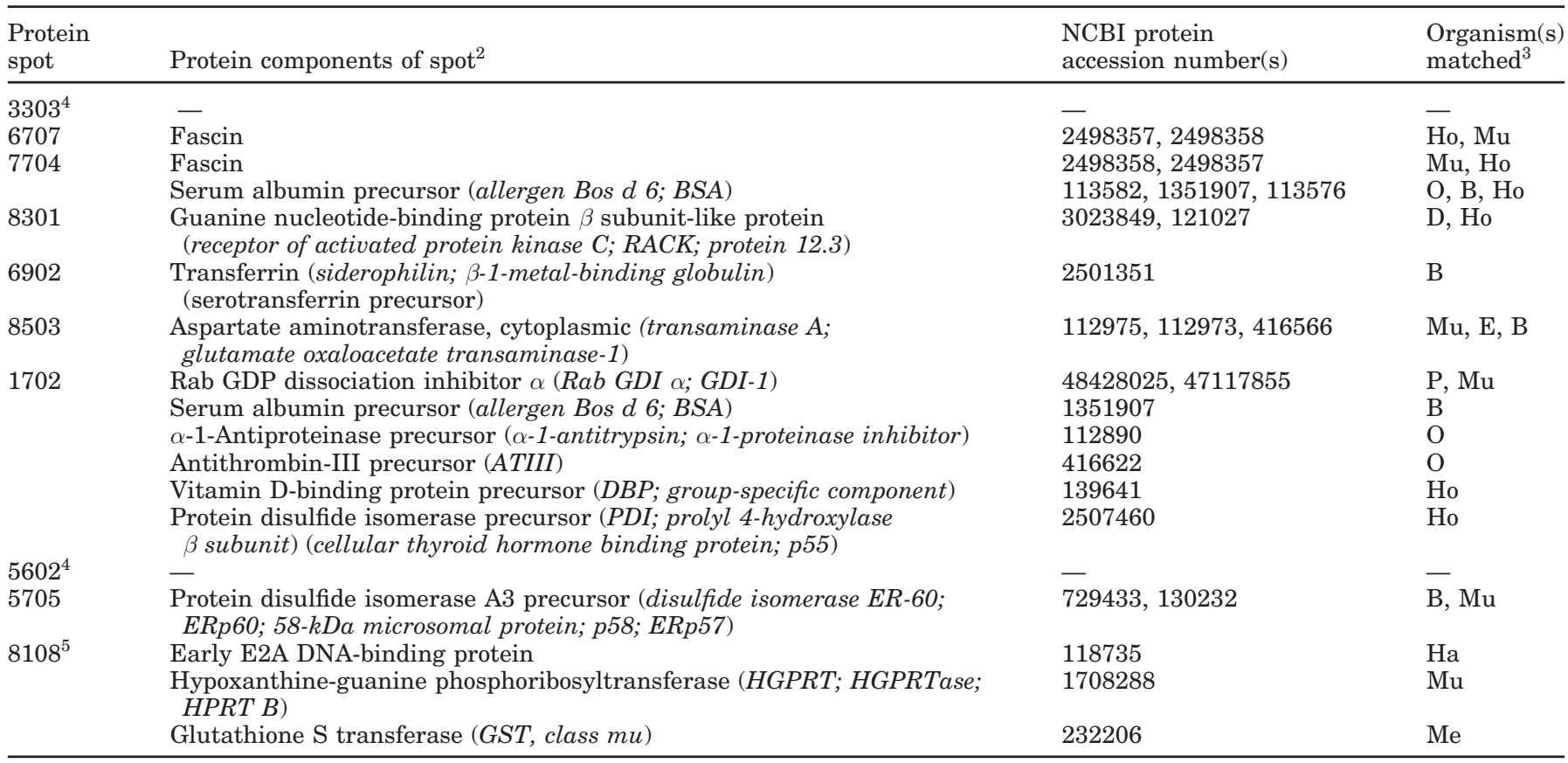

\footnotetext{
${ }^{1} \mathrm{NCBI}=$ National Center for Biotechnology Information.
}

${ }^{2}$ Roman typeface indicates common name for a given protein; italicized terms in parentheses indicate synonymous names for the protein.

${ }^{3} \mathrm{Ho}=$ Homo sapiens (human); $\mathrm{Mu}=$ Mus musculus (house mouse); $\mathrm{O}=$ Ovis aries (sheep); $\mathrm{B}=$ Bos taurus (cow); $\mathrm{D}=$ Danio rerio (zebrafish); $\mathrm{E}=$ Equus caballus (horse); $\mathrm{P}=$ Pongo pygmaeus (orangutan); $\mathrm{Ha}=$ human adenovirus type $4 ; \mathrm{Me}=$ Mesocricetus auratus (golden hamster).

${ }^{4}$ Protein spot was damaged during preparation for mass spectrometrIC analysis and was subsequently not included in further analyses.

${ }^{5}$ Keratin was detected in the sample; results not reported.

Table 3. Components of protein spots determined by mass spectrometry (batch 2$)^{1}$

\begin{tabular}{|c|c|c|c|}
\hline $\begin{array}{l}\text { Protein } \\
\text { spot }\end{array}$ & Protein components of spot ${ }^{2}$ & $\begin{array}{l}\text { NCBI protein } \\
\text { accession number(s) }\end{array}$ & $\begin{array}{l}\text { Organism(s) } \\
\text { matched }^{3}\end{array}$ \\
\hline \multirow[t]{2}{*}{$7801^{4}$} & WD-repeat protein 1 (actin interacting protein 1; AIP1) & 12230747 & $\mathrm{Mu}$ \\
\hline & Fibrinogen $\gamma$-B chain precursor & 120140 & B \\
\hline $2607^{4}$ & Fibrinogen $\gamma$-B chain precursor & 120140,1346007 & $\mathrm{~B}, \mathrm{R}$ \\
\hline \multirow[t]{3}{*}{2402} & Annexin A8 (annexin VIII) & 12585137 & $\mathrm{Mu}$ \\
\hline & Glandular kalikren K24 precursor (tissue kallikrein $24 ; m G K-24$ ) & 48428341 & $\mathrm{Mu}$ \\
\hline & Elongation factor $\mathrm{Tu}(E F-T u)$ & 37999596 & $\mathrm{P}$ \\
\hline $6701^{4}$ & $\begin{array}{l}\text { Aldehyde dehydrogenase 1A1 (aldehyde dehydrogenase, cytosolic; } \\
\text { ALDH class } 1 ; \text { ALDHII; ALDH-E1) }\end{array}$ & $118494,42558919,1706388$ & $\mathrm{E}, \mathrm{Ma}, \mathrm{O}$ \\
\hline $2606^{4,5}$ & - & - & - \\
\hline 7102 & $\begin{array}{l}\text { Proteasome subunit } \beta \text { type } 2 \text { (macropain subunit } C 7-1 \text {; multicatalytic } \\
\text { endopeptidase complex subunit } C 7-1 \text { ) }\end{array}$ & 9910832 & $\mathrm{Mu}$ \\
\hline $7502^{4,5}$ & - & - & - \\
\hline $3505^{4}$ & $\begin{array}{l}26 \mathrm{~S} \text { proteasome non-ATPase regulatory subunit } 13 \text { (26S proteasome } \\
\text { regulatory subunit S11; } 26 \mathrm{~S} \text { proteasome regulatory subunit p40.5) }\end{array}$ & 20978558 & $\mathrm{H}$ \\
\hline 7101 & Glutathione $\mathrm{S}$ transferase $\mathrm{P}(G S T$, class pi) & 121744,121746 & $\mathrm{~B}, \mathrm{H}$ \\
\hline 2403 & Complement C3 precursor (contains C3a anaphylatoxin) & 116594 & $\mathrm{H}$ \\
\hline $5605^{4}$ & Selenium-binding protein 1 (56-kDa selenium-binding protein) & 6094240,134259 & $\mathrm{H}, \mathrm{Mu}$ \\
\hline \multirow[t]{2}{*}{4601} & Serum albumin precursor & 113576,1351907 & $\mathrm{H}, \mathrm{B}$ \\
\hline & Actin-like protein (actin-2) & 30581042 & $\mathrm{D}$ \\
\hline
\end{tabular}

\footnotetext{
${ }^{1} \mathrm{NCBI}=$ National Center for Biotechnology Information.
}

${ }^{2}$ Roman typeface indicates common name for a given protein; italicized terms in parentheses indicate synonymous names for the protein.

${ }^{3} \mathrm{Mu}=$ Mus musculus (house mouse); $\mathrm{B}=$ Bos taurus (cow); $\mathrm{R}=$ Rattus norvegicus (Norway rat); $\mathrm{P}=$ Pseudomonas syringae pv. Tomato; $\mathrm{E}=$ Equus caballus (horse); $\mathrm{Ma}=$ Macaca fascicularis (crab-eating macaque); $\mathrm{O}=$ Ovis aries (sheep); $\mathrm{H}=$ Homo sapiens (human); $\mathrm{D}=$ Drosophila melanogaster (fruitfly).

${ }^{4}$ Keratin(s) were detected in the sample; results not reported.

${ }^{5}$ The major protein identified in the sample was keratin; results not reported. 


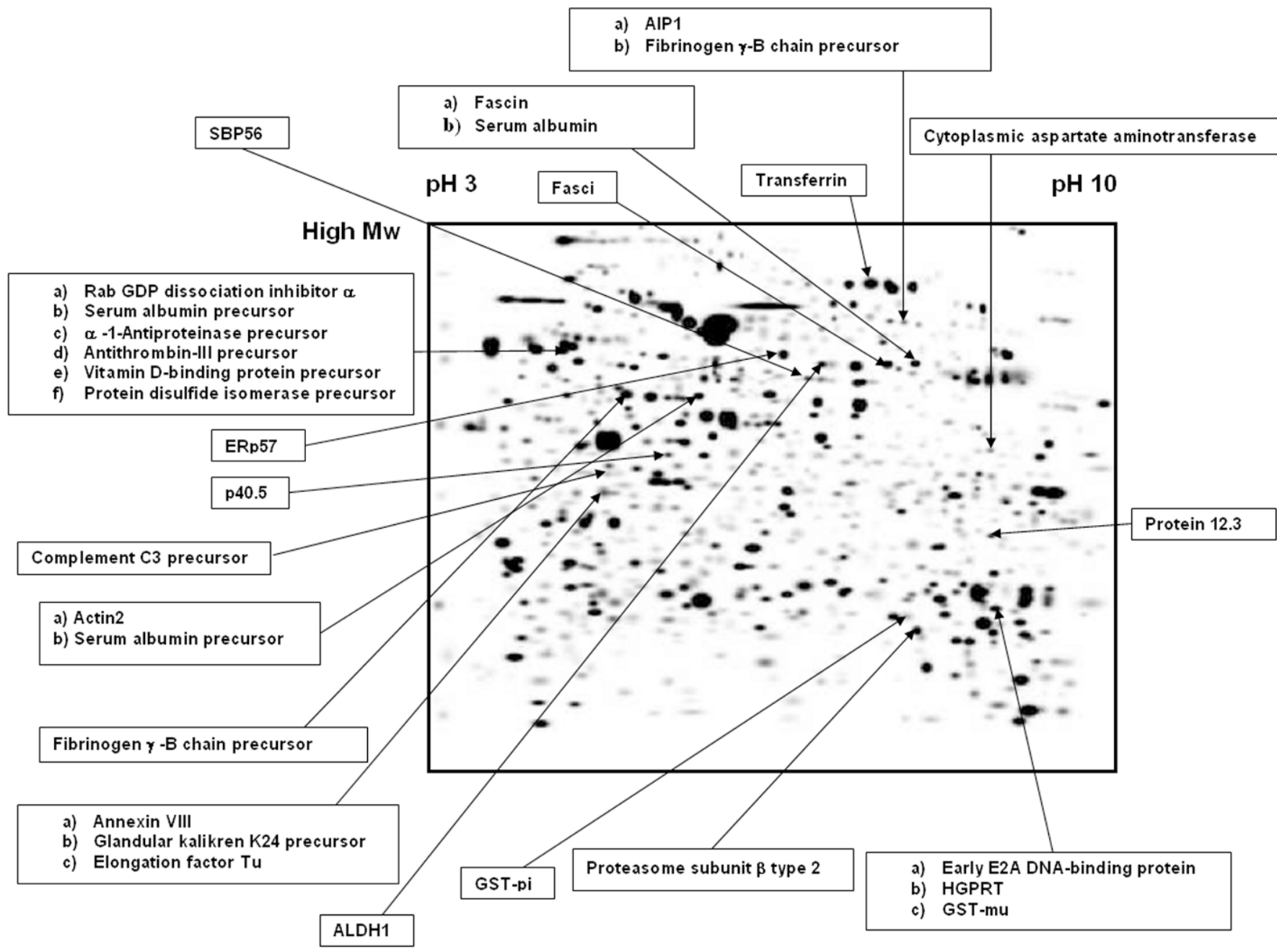

Figure 2. Master Image from Matchset with protein annotations. AIP1 = actin interacting protein 1; SBP56 = 56-kDa cytosolic protein selenium-binding protein 1; GDP = guanine diphosphate; ERp57 = protein disulfide isomerase A3 precursor; ALDH1 = aldehyde dehydrogenase 1A1; GST-pi = glutathione S transferase, class pi; GST-mu = glutathione S transferase, class mu; HGPRT = hypoxanthine-guanine phosphoribosyltransferase.

contained differentially expressed levels of several heat stress-related proteins support this proposition (see ensuing discussion).

\section{Protein Spot 6902-Transferrin}

Protein spot 6902 was identified as transferrin (Figure 2, Tables 1 and 2). Transferrins are synthesized by the liver and secreted as serum proteins but are also locally produced by the mammary gland. Lee et al. (1987) documented that in virgin mice, small amounts of transferrin are locally produced by epithelial cells in the mammary gland and that its synthesis increases throughout gestation and lactation. Chen and Bissel (1987) observed that transferrin expression in primary mouse mammary epithelial cells was greatly elevated when cells were grown on a reconstituted basement membrane matrix, as compared with tissue culture plastic. This observation has led researchers to propose that changes in extracellular matrix structure and composition may also regulate mammary transferrin concentrations. Furthermore, and especially relevant to the current study, milk transferrin concentrations in lactating rats can be modulated by restricting either total food intake or the protein content of the diet, without altering serum concentrations of transferrin (Grigor et al., 1988).

Growing evidence suggests that transferrin synthesis is associated with growth and functional differentiation in nonhepatic tissues. Results from in vitro studies using the bovine mammary epithelial cell line MAC-T showed that MAC-T cells proliferate in response to the 
addition of transferrin to serum-free, but not serumcontaining, media (Rejman et al., 1992). In primary cell culture experiments using sheep bladder smooth muscle cells, Weinzimer et al. (2001) demonstrated that transferrin and IGF-binding protein-3 (IGFBP-3) were both growth-potentiating when added to serum-free media, but when the 2 proteins were co-incubated with the cells in serum-free media, growth was dramatically reduced. This, along with other experiments, demonstrated for the first time that transferrin is an IGFBP3-binding protein (Weinzimer et al., 2001). Weinzimer et al. (2001) explained that the observed effects in cell culture are consistent with transferrin/IGFBP-3 binding with such affinity as to prevent either ligand from interacting with its usual surface receptor. Despite these observations, the relationship between transferrin and the IGF/IGFBP-3 axis is still poorly characterized.

In pubertal girls, serum concentrations of transferrin are positively correlated with IGF-I and IGFBP-3 (Wilson et al., 1991; Wilson et al., 1992). Insulin-like growth factor-I also up-regulates the expression of cell-surface transferrin receptors, apparently by redistributing intracellular transferrin receptors to the cell surface (Davis and Czech, 1986, 1987; Lombardi et al., 1989). This prompted the speculation that the sequestration or presentation of IGF-I to the cell surface by IGFBP3 may indirectly influence cell growth by regulating transferrin receptor density at the cell surface (Weinzimer et al., 2001).

In the bovine, the major site of IGF-I mRNA synthesis is in the liver, but there is additional synthesis by peripheral tissues, including the mammary gland. Insulin-like growth factor-binding proteins are known to regulate the physiological actions of IGF-I by controlling its availability to cells (Thissen et al., 1994); approximately $95 \%$ of circulating IGF-I is bound to IGFBP-3, the predominant IGFBP in serum (Clemmons, 1993). Serum concentrations of IGF-I are generally increased in heifers reared on a high feeding level (Vestergaard et al., 1995). Additionally, Weber et al. (1999) showed that IGFBP-3 is also up-regulated in overfed heifers and that excess IGFBP-3 can block the mitogenic effects of IGF-I in vitro. This last finding is contradictory to what Weinzimer et al. (2001) found when IGFBP-3 was added to sheep bladder smooth muscle cells in culture and likely reflects species, tissue, or cell culture technique differences. The conjecture regarding cell culture technique is based on the varying definition of "basal media" among different laboratory groups. In the study conducted by Weinzimer et al. (2001), the basal media were serum, and was thus transferrin free. However, in the study by Weber et al. (1999), the basal media contained transferrin (5 mg/L).
Thus, on the surface it may seem that the 2 studies are contradictory, but when considered in total, both studies suggest that the addition of transferrin and IGFBP-3 to the media of cultured cells is not growth promoting.

Because of our tissue separation protocol and considerable sequence homology between the 2 mentioned types of transferrin, we were unable to distinguish whether the divergent transferrin levels detected in the current experiment were serum or mammary derived in origin. However, it is likely that the transferrin detected was of mammary origin. This is based on our findings that transferrin levels were highest in E-heifers as opposed to R-heifers $(P<0.018)$. These results tend to agree with Grigor et al. (1988), based on the assumption that transferrin concentrations in mammary tissue are positively correlated with milk transferrin concentration. Increased levels of transferrin in E-heifers may have resulted from the up-regulation of IGF-I and IGFBP-3 previously observed in heifers reared on elevated planes of nutrition.

\section{Protein Spot 5705-Protein Disulfide Isomerase A3 Precursor}

Protein spot 5705 was identified as protein disulfide isomerase (PDI) A3 precursor (ERp57; Figure 2, Tables 1 and 2), a member of the PDI family. All proteins of the PDI family are present in the endopolasmic reticulum (ER) lumen, and ERp57 has also been found in cytosol (Lewis et al., 1986). In the ER, PDI serve as chaperones, and are therefore involved with the proper folding of proteins and disulfide bond formation in proteins that are destined to be secreted or incorporated into the cell membrane (Turano et al., 2002). However, their role in the cytosol is less clear; they may maintain the same functions as ER-bound PDI, but have uniquely been shown to become complexed with STAT3 (the protein responsible for signal transduction and transcription regulation) in the cytosol of liver cells (Ndubuisi et al., 1999). A proposed role for mammary cytoplasmic ERp57 has yet to be defined. Likewise, the physiological significance of the protein's developmental regulation remains a question. In the current study, we found the expression levels of ERp57 to be approximately 1.5-fold higher in 200-kg heifers compared with $350-\mathrm{kg}$ heifers $(P<0.01)$.

\section{Protein Spot 6701-Aldehyde Dehydrogenase 1A1}

Protein spot 6701 was identified as the cytosolic enzyme aldehyde dehydrogenase 1A1 (ALDH1; Figure 2, Tables 1 and 3). The enzyme ALDH1 plays a critical role in vitamin A (retinol) metabolism by aiding in the 
conversion of vitamin A to its bioactive metabolite, retinoic acid. Retinoic acid has been shown to inhibit IGFI-stimulated bovine mammary epithelial cell proliferation in culture (Woodward et al., 1996; Purup et al., 2001, Cheli et al., 2003). Retinoic acid may inhibit growth by increasing the local secretion of certain IGFBP, which could modulate the growth-promoting effects of IGF-I. Increased ALDH1 activity is presumed to contribute to the active pool of vitamin A metabolites, and therefore possibly the inhibition of IGF-I-stimulated mammary growth. In the current study, ALDH1 protein expression was increased in E-heifers rather than R-heifers $(P<0.08)$, which is consistent with past hypotheses that increased planes of nutrition impair heifer mammary development. However, E- and R-heifers in the current study had similar mammary epithelial cell proliferation and parenchymal DNA accretion rates (Meyer et al., 2006b). This observation suggests that plane of nutrition has no direct effect on prepubertal mammary development.

\section{Protein Spot 3505-26S Proteasome Regulatory Subunit p40.5}

Protein spot 3505 was identified as a regulatory subunit of the 26S proteasome (p40.5; Figure 2, Tables 1 and 3). To understand possible roles of this particular regulatory subunit, a brief review of nonlysosomal protein catabolism is required. In the cytosol, abnormally folded and short-lived proteins are subjected to degradation by a process that requires ATP and ubiquitination of the protein in question. Ubiquitin is a protein that can be thought of as a tag for destruction, and the more ubiquitin molecules are attached to a single protein, the more effective is the signal for destruction. Ubiquitin covalently binds to the protein destined to be degraded. Upon arrival at the cytosolic $26 \mathrm{~S}$ proteasome, the ubiquitin-protein complex is subjected to proteolysis. The 26S proteasome is itself composed of 2 components, a $20 \mathrm{~S}$ proteasome that contains catalytic activity, and a 19S regulatory subunit that binds to polyubiquitin chains and thus regulates the entry of ubiquitintagged proteins into the $20 \mathrm{~S}$ proteasome (Berg et al., 2002). The protein identified in the current experiment is a subunit of the $19 \mathrm{~S}$ regulatory subunit of the $26 \mathrm{~S}$ proteasome. Although the function of p40.5 is not fully understood, its yeast homolog, non-ATPase subunit 7, has been characterized (Hori et al. 1998). Disruption of the non-ATPase subunit 7 gene in yeast was not lethal, but prevented proliferation of affected cells at $37^{\circ} \mathrm{C}$, suggesting that the function of the $26 \mathrm{~S}$ proteasome is impaired under heat stress (Hori et al., 1998). Furthermore, the calculated $\mathrm{Mw}$ and $\mathrm{pI}$ for human $\mathrm{p} 40.5,49.2 \mathrm{kDa}$, and 5.46 , respectively, as reported by
Hori et al. (1998), are very similar to the approximated values reported here of $45.5 \mathrm{kDa}$ and 5.28 . In the current study, R-heifers expressed almost 1.2-fold more $(P$ $<0.14)$ of this regulatory subunit than did E-heifers. The reasoning for this is speculative at best but may reflect a response to heat stress in animals reared on the $\mathrm{E}$ intake diet.

\section{Protein Spot 7102-Proteasome Subunit $\beta$ Type 2}

Protein spot 7102 was identified as proteasome subunit $\beta$ type 2 (Figure 2, Tables 1 and 3). This particular subunit of the $20 \mathrm{~S}$ component of the $26 \mathrm{~S}$ proteasome is known to have endopeptidase activity similar to that of chymotrypsin and a calculated $\mathrm{Mw}$ of $22.8 \mathrm{kDa}$ (Nothwang et al., 1994). Through our 2D-PAGE experiments, we found this protein to have an approximate $\mathrm{Mw}$ of $22.9 \mathrm{kDa}$ and $\mathrm{a} \mathrm{pI}$ of 6.97 . We also found that E-heifers expressed this subunit at levels nearly 1.3 -fold those of R-heifers $(P<0.09)$; however, the relevance of this result to heifer mammary development is unknown. As with the $26 \mathrm{~S}$ proteasome regulatory subunit $\mathrm{p} 40.5$ discussed previously, expression of this component of the $26 \mathrm{~S}$ proteasome may correlate to a stress response in animals reared on an $\mathrm{E}$ plane of nutrition.

\section{Protein Spot 7101-Glutathione S Transferase, Class Pi}

Protein spot 7101 was identified as glutathione S transferase (GST), class pi (GST-pi; Figure 2, Tables 1 and 3). Glutathione $\mathbf{S}$ transferases are cytoplasmic proteins known to protect cells from oxidative stress by metabolizing oxidative stressors. Huang et al. (2003) recently found that GST-pi-positive infiltrative ductal breast carcinomas in women are more aggressive and have a poorer prognosis than do corresponding GST-pinegative tumors. This implies the persistent presence of an oxidative stressor in tumors that demonstrate upregulated GST-pi activity. In this light, GST-pi expression is positively correlated with mammary cell proliferation. In our experiment, E-heifers expressed more GST-pi than did R-heifers $(P<0.15)$. This correlates with a tendency for increased cell proliferation observed in E-heifers, as assessed by the 5-bromo-2-deoxyuridine-labeling index (Meyer et al., 2006b). Alternatively, it may suggest that heifers reared on $\mathrm{E}$ planes of nutrition are exposed to more oxidative stressors than heifers reared on $R$ planes of nutrition.

\section{Protein Spot 2403-Complement C3 Precursor (Contains C3a Anaphylatoxin)}

Protein spot 2403 was identified as complement C3 precursor (Figure 2, Tables 1 and 3). From its AA se- 
quence, it was found to contain C3a anaphylatoxin. C3a anaphylatoxin is a mediator of local inflammatory processes. Factor $\mathrm{C} 3$ helps activate the complement system; its synthesis is increased during acute inflammation (Alexander et al., 1978). Humans with homozygous C3 deficiency often suffer from recurrent pyogenic infections such as pneumonia and septicemia; the absence of C3 is oftentimes lethal (Alper et al., 1976; Roord et al., 1983). In our experiment, heifers weighing $200 \mathrm{~kg}$ expressed over 2-fold more complement C3 precursor $(P<0.05)$ than heifers weighing $350 \mathrm{~kg}$. Perhaps the tissue remodeling that results from prepubertal allometric mammary growth in 200-kg heifers involves acute inflammation, and $\mathrm{C} 3$ production is increased to combat it.

\section{Protein Spot 5605-Selenium-Binding Protein 1}

Protein spot 5605 was identified as the $56-\mathrm{kDa}$ cytosolic protein selenium-binding protein 1 (SBP56; Figure 2, Tables 1 and 3). Selenium-binding protein 1 was originally discovered as a protein that binds exogenously administered radioactive selenium (Bansal et al., 1989, 1990). The exact physiological role of this protein has not been well characterized. Porat et al. (2000) suggested that SBP56 participates in intra-Golgi vesicular transport, whereas Miyaguchi (2004) suggested that SBP56 may be involved in the initial sequential events in rapid cell growth, such as determining the direction of cell outgrowth and recruitment of actin monomers. Observations by Flemetakis et al. (2002) suggest that SBP56 expression varies at different developmental stages. This is consistent with our finding that SBP56 protein expression was higher in $350-\mathrm{kg}$ animals than in $200-\mathrm{kg}$ animals $(P<0.06)$. Furthermore, Chen and others (2004) reported that low levels of SBP56 expression were present in human lung tumors with high overall proliferation status. In the current study, the mammary glands of heifers harvested at a BW of $200 \mathrm{~kg}$ were growing at an allometric rate, whereas those harvested at a $\mathrm{BW}$ of $350 \mathrm{~kg}$ were growing at an isometric rate (Meyer et al., 2006b). The observations of Chen et al. (2004) appear to agree with our finding that SBP56 protein expression was higher in the $200-\mathrm{kg}$ rather than the $350-\mathrm{kg}$ heifers.

\section{Other Miscellaneous Proteins}

Several other proteins were detected in our analyses but are not discussed in detail, either because their significance to heifer mammary development is completely unknown or because several proteins migrated to the same point, making discussion of individual proteins composing these spots problematic. However, the names and some characteristics of these proteins are listed in Tables 1, 2, and 3.

\section{General Discussion}

Because this was the first large-scale proteomics experiment conducted with bovine peripubertal mammary parenchyma cytosol, we chose to use laboratory products that separate a broad range of proteins. For instance, the IPG strips that we used for our first-dimension separation covered a $\mathrm{pH}$ range from 3 to 10 ; narrower range strips are available and should be used in the future to increase the resolution of individual protein spots. We also used gradient gels in our seconddimension separation; single-percentage gels should be considered for use in future experiments.

We detected a total of 820 proteins in our experiment. This is likely an underestimate because the Sypro Ruby protein gel stain is light sensitive and our stained gels were exposed to ambient light before scanning. Therefore, some loss of signal intensity may have occurred during this time.

Cellular heterogeneity seemed to be an issue in our experiment owing to the detection of several plasma proteins such as albumin and fibrinogen precursors. In the future, tissue or cell-separation protocols leading to more homogenous samples could be used. Possible options for this include using centrifugal columns to remove large-Mw plasma proteins, or laser-capture microscopy to isolate individual cells of interest.

The second batch of protein plugs that was processed by the VBI contained keratin contamination, which is a major concern with proteomics experiments because of the sensitivity of the mass spectrometry equipment. All possible measures were taken in the handling of samples not to introduce contaminants, but it appears some contamination was present. Keratins of various varieties were detected in nearly the entire second batch of samples, but only once in the first. Because both batches of samples submitted to the VBI were cut on the same day from the same gel and were processed in the same manner, we are confident that the keratin was an artifact of gel handling and did not contribute to the differential protein expression of the proteins in the second batch.

\section{CONCLUSIONS}

Through our 2D-PAGE experiments, we found that the protein composition of bovine mammary cytosol fluctuated according to the physiological and nutritional state of heifers. Furthermore, through mass spectrometric analyses, we identified several differentially expressed proteins. In conclusion, the establishment of 
a proteomic map of Holstein heifer mammary parenchyma offers virtually unlimited discovery potential and can serve as a launch point for further studies of heifer mammary development. Many proteins identified here can readily be examined further, through either Western and ligand blot analyses, in vitro cell culture experiments, or immunohistochemistry experiments, to name a few. These approaches will help us to better understand the relative abundance of, ligands for, mitogenic properties of, and cellular localization of proteins of interest.

\section{ACKNOWLEDGMENTS}

The authors would like to thank K. Lee and R. Settlage for their technical assistance with proteomic laboratory work and mass spectrometric analyses, respectively. Additionally, we would like to acknowledge J. McFadden, M. Miller, D. Shaw, B. Berggren-Thomas, and J. Kelsey-Mills for their assistance with animal care and tissue collection.

\section{REFERENCES}

Aksu, S., C. Scheler, N. Focks, F. Leenders, F. Theuring, J. Salnikow, and P. R. Jungblut. 2002. An iterative calibration method with prediction of post-translational modifications for the construction of a two-dimensional electrophoresis database of mouse mammary gland proteins. Proteomics 2:1452-1463.

Alexander, J. W., C. K. Ogle, J. D. Stinnett, and B. G. MacMillan. 1978. A sequential, prospective analysis of immunologic abnormalities and infection following severe thermal injury. Ann. Surg. 188:809-816.

Alper, C. A., H. R. Colten, J. S. S. Gear, A. R. Rabson, and F. S. Rosen. 1976. Homozygous human C3 deficiency: The role of C3 in antibody production, C-1s-induced vasopermeability, and cobra venom-induced passive hemolysis. J. Clin. Invest. 57:222-229.

Anbazhagan, R., P. P. Osin, J. Bartkova, B. Nathan, E. B. Lane, and B. Gusterson. 1998. The development of epithelial phenotypes in the human fetal and infant breast. J. Pathol. 184:197-206.

Bansal, M. P., T. Mukhopadhyay, J. Scott, R. G. Cook, R. Mukhopadhyay, and D. Medina. 1990. DNA sequencing of a mouse liver protein that binds selenium: Implications for selenium's mechanism of action in cancer prevention. Carcinogenesis 11:20712073.

Bansal, M. P., C. J. Oborn, K. G. Danielson, and D. Medina. 1989. Evidence for two selenium-binding proteins distinct from glutathione peroxidase in mouse liver. Carcinogenesis 10:541-546.

Berg, J. M., J. L. Tymoczko, and L. Stryer. 2002. Biochemistry. 5th ed. W. H. Freeman and Co., New York, NY.

Cheli, F., I. Politis, L. Rossi, E. Fusi, and A. Baldi. 2003. Effects of retinoids on proliferation and plasminogen activator expression in a bovine mammary epithelial cell line. J. Dairy Res. 70:367-372.

Chen, L.-H., and M. J. Bissel. 1987. Transferrin mRNA level in the mouse mammary gland is regulated by pregnancy and extracellular matrix. J. Biol. Chem. 262:17247-17250.

Chen, G., H. Wang, C. T. Miller, D. G. Thomas, T. G. Gharib, D. E. Misek, T. J. Giordano, M. B. Orringer, S. M. Hanash, and D. G. Beer. 2004. Reduced selenium-binding protein 1 expression is associated with poor outcome in lung adenocarcinomas. For. Pathol. 202:321-329.

Clemmons, D. R. 1993. IGF binding proteins and their functions. Mol. Reprod. Dev. 35:368-375.

Daniels, K. M., M. L. McGilliard, P. L. Boyle, M. J. Meyer, M. E. Van Amburgh, A. V. Capuco, and R. M. Akers. 2005. Effects of body weight and plane of nutrition on histological development of mammary tissue in Holstein heifers. J. Dairy Sci. 88(Suppl. 1):288. (Abstr.)

Davis, R. J., and M. P. Czech. 1986. Regulation of transferrin receptor expression at the cell surface by insulin-like growth factors, epidermal growth factor and platelet-derived growth factor. EMBO J. 5:653-658.

Davis, R. J., M. Faucher, L. K. Racaniello, A. Carruthers, and M. P. Czech. 1987. Insulin-like growth factor I and epidermal growth factor regulate the expression of transferrin receptors at the cell surface by distinct mechanisms. J. Biol. Chem. 262:13126-13134.

Flemetakis, E., A. Agalou, N. Kavroulakis, M. Dimou, A. Martsikovskaya, A. Slater, H. P. Spaink, A. Roussis, and P. Katinakis. 2002. Lotus japonicus gene Ljsbp is highly conserved among plants and animals and encodes a homologue to the mammalian seleniumbinding proteins. Mol. Plant Microbe Interact. 15:313-322.

Grigor, M. R., A. Carne, A. Geursen, and D. J. Flint. 1988. Effect of extended lactation and diet on transferrin concentrations in rat milk. J. Nutr. 118:669-674.

Grothey, A., R. Hashizume, A. A. Sahin, and P. D. McCrea. 2000. Fascin, an actin-bundling protein associated with cell motility, is upregulated in hormone receptor negative breast cancer. Br. J. Cancer 83:870-873.

Guvakova, M. A., D. Boettiger, and J. C. Adams. 2002. Induction of fascin spikes in breast cancer cells by activation of the insulin-like growth factor-I receptor. Int. J. Biochem. Cell Biol. 34:685-698.

Hammon, H. M., R. M. Bruckmaier, U. E. Honegger, and J. W. Blum. 1994. Distribution and density of $\alpha$ - and $\beta$-adrenergic receptor binding sites in the bovine mammary gland. J. Dairy Res. 61:47-57.

Hori, T., S. Kato, M. Saeki, G. N. DeMartino, C. A. Slaughter, J. Takeuchi, A. Toh-e, and K. Tanaka. 1998. cDNA cloning and functional analysis of p28 (Nas6p) and p40.5 (Nas7p), two novel regulatory subunits of the $26 \mathrm{~S}$ proteasome. Gene 216:113-122.

Huang, J., P. H. Tan, J. Thiyagarajan, and B. H. Bay. 2003. Prognostic significance of glutathione S-transferase-pi in invasive breast cancer. Mod. Pathol. 16:558-565.

Inderwies, T., M. W. Pfaff, H. H. D. Meyer, J. W. Blum, and R. M. Bruckmaier. 2003. Detection and quantification of mRNA expression of $\alpha$ - and $\beta$-adrenergic receptor subtypes in the mammary gland of dairy cows. Domest. Anim. Endocrinol. 24:123-135.

Kadowaki, T., S. Koyasu, E. Nishida, H. Sakai, F. Takaku, I. Yahara, and M. Kasuga. 1986. Insulin-like growth factors, insulin, and epidermal growth factor cause rapid cytoskeletal reorganization in KB cells. J. Biol. Chem. 261:16141-16147.

Lee, E. Y., M. H. Barcellos-Hoff, L. H. Chen, G. Parry, and M. J. Bissell. 1987. Transferrin is a major mouse milk protein and is synthesized by mammary epithelial cells. In Vitro Cell. Dev. Biol. 23:221-226.

Lewis, M. J., R. A. Mazzarella, and M. Green. 1986. Structure and assembly of the endoplasmic reticulum: Biosynthesis and intracellular sorting of ERp61, ERp59, and ERp49, three protein components of murine endoplasmic reticulum. Arch. Biochem. Biophys. 245:389-403.

Lombardi, A., D. Tramontano, L. E. Braverman, and S. H. Ingbar. 1989. Transferrin in FRTL5 cells: Regulation of its receptor by mitogenic agents and its role in growth. Endocrinology 125:652-658.

Meyer, M. J., A. V. Capuco, D. A. Ross, L. M. Lintault, and M. E. Van Amburgh. 2006a. Developmental and nutritional regulation of the prepubertal heifer mammary gland: I. Parenchyma and fat pad mass and composition. J. Dairy Sci. 89:4289-4297.

Meyer, M. J., A. V. Capuco, D. A. Ross, L. M. Lintault, and M. E. Van Amburgh. 2006b. Developmental and nutritional regulation of the prepubertal bovine mammary gland: II. Epithelial cell proliferation, parenchymal accretion rate, and allometric growth. J. Dairy Sci. 89:4298-4304.

Miyaguchi, K. 2004. Localization of selenium-binding protein at the tips of rapidly extending protrusions. Histochem. Cell Biol. 121:371-376. 
Ndubuisi, M. I., G. G. Guo, V. A. Fried, J. D. Etlinger, and P. B. Sehgal. 1999. Cellular physiology of STAT3: Where is the cytoplasmic monomer? J. Biol. Chem. 274:25499-25509.

Nothwang, H. G., T. Tamura, K. Tanaka, and A. Ichihara. 1994 Sequence analyses and inter-species comparisons of three novel human proteasomal subunits, HsN3, HsC7-I, and HsC10-II, confine potential proteolytic active-site residues. Biochim. Biophys. Acta 1219:361-368.

Porat, A., Y. Sagiv, and Z. Elazar. 2000. A 56-kDa selenium-binding protein participates in intra-Golgi protein transport. J. Biol. Chem. 275:14457-14465.

Purup, S., S. K. Jensen, and K. Sejrsen. 2001. Differential effects of retinoids on proliferation of bovine mammary epithelial cells in collagen gel culture. J. Dairy Res. 68:157-164.

Rejman, J. J., S. P. Oliver, R. A. Muenchen, and J. D. Turner. 1992. Proliferation of the MAC-T bovine mammary epithelial cell line in the presence of mammary secretion whey proteins. Cell Biol. Int. Rep. 16:993-1001.

Resnik, J. L., D. B. Reichardt, K. Huety, N. J. G. Webster, and B. L. L. Seely. 1998. Elevated insulin-like growth factor-I receptor autophosphorylation and kinase activity in human breast cancer. Cancer Res. 58:1159-1164.

Roord, J. J., M. Daha, W. Kuis, H. A. Verbrugh, Y. Verhoef, B. J. M. Zegers, and J. W. Stoop. 1983. Inherited deficiency of the third component of complement associated with recurrent pyogenic infections, circulating immune complexes, and vasculitis in a Dutch family. Pediatrics 71:81-87.

Sejrsen, K. 1994. Relationships between nutrition, puberty, and mammary development in cattle. Proc. Nutr. Soc. 53:103-111.

Sejrsen, K., J. T. Huber, H. A. Tucker, and R. M. Akers. 1982. Influence of nutrition on mammary development in pre- and postpubertal heifers. J. Dairy Sci. 65:793-800.

Sinha, Y. N., and H. A. Tucker. 1969. Mammary development and pituitary prolactin level of heifers from birth through puberty and during the estrous cycle. J. Dairy Sci. 52:507-512.

Talamo, F., C. D’Ambrosio, S. Arena, P. Del Vecchio, L. Ledda, G. Zehender, L. Ferrara, and A. Scaloni. 2003. Proteins from bovine tissues and biological fluids: Defining a reference electrophoresis map for liver, kidney, muscle, plasma, and red blood cells. Proteomics 3:440-460.

Thissen, J. P., J.-M. Ketelslegers, and L. E. Underwood. 1994. Nutritional regulation of the insulin-like growth factors. Endocr. Rev. 15:80-101.

Turano, C., S. Coppari, F. Altieri, and A. Ferraro. 2002. Proteins of the PDI family: Unpredicted non-ER locations and functions. J. Cell. Physiol. 193:154-163.

Vestergaard, M., S. Purup, and K. Sejrsen. 1995. Influence of bovine growth hormone and feeding level on growth and endocrine status of prepubertal heifers. J. Anim. Sci. 73 (Suppl. 1):148. (Abstr.)

Waksman, M., A. Shamay, and A. Gertler. 1991. Bovine pituitary, kidney, uterine and mammary gland extracts contain bovine mammary epithelium growth factors that synergise with IGF-I and fetal calf serum: Indication for involvement of GTP-binding proteins. Domest. Anim. Endocrinol. 8:271-280.

Weber, M. S., S. Purup, M. Vestergaard, S. E. Ellis, J. SøndergårdAndersen, R. M. Akers, and K. Sejrsen. 1999. Contribution of insulin-like growth factor (IGF)-I and IGF binding protein-3 to mitogenic activity in bovine mammary extracts and serum. J. Endocrinol. 161:365-373.

Weinzimer, S. A., T. Beers Gibson, P. F. Collett-Solberg, A. Khare, B. Liu, and P. Cohen. 2001. Transferrin is an insulin-like growth factor-binding protein-3 binding protein. J. Clin. Endocrinol. Metab. 86:1806-1813.

Wilson, D. M., J. D. Killen, L. D. Hammer, I. F. Litt, C. Vosti, B. Miner, C. Hayward, and C. B. Taylor. 1991. Insulin-like growth factor-I as a reflection of body composition, nutrition, and puberty in sixth and seventh grade girls. J. Clin. Endocrinol. Metab. 73:907-912.

Wilson, D. M., M. A. Stene, J. D. Killen, L. D. Hammer, I. F. Litt, C. Hayward, and C. B. Taylor. 1992. Insulin-like growth factor binding protein-3 in normal pubertal girls. Acta Endocrinol. (Copenh.) 126:381-386.

Woodward, T. L., J. D. Turner, H. T. Hung, and X. Zhao. 1996. Inhibition of cellular proliferation and modulation of insulin-like growth factor binding proteins by retinoids in a bovine mammary epithelial cell line. J. Cell. Physiol. 167:488-499. 